\title{
EFEKTIVITAS GEL EKSTRAK BUNGA KECOMBRANG (Etlingera elatior) SEBAGAI ANTIINFLAMASI TERHADAP MENCIT YANG DIINDUKSI KARAGENAN
}

\section{(EFFECTIVENESS OF KECOMBRANG FLOWER EXTRACT GEL (Etlingera elatior) AS ANTIINFLAMATION ON CARRAGEENAN INDUCED MICE)}

\author{
I GUSTI AGUNG AYU KUSUMA WARDANI ${ }^{\bullet}$ \\ ${ }^{1}$ Prodi D3 Farmasi Fakultas Farmasi Universitas Mahasaraswati Denpasar \\ Jalan Kamboja No 11A, Denpasar, Bali
}

\begin{abstract}
Abstrak: Antiinflamasi merupakan obat yang memiliki aktivitas menekan atau mengurangi peradangan. Di Indonesia terdapat begitu banyak tanaman obat herbal yang dapat digunakan sebagai antinflamasi. Salah satu tanaman yang dipercaya secara empiris mempunyai khasiat sebagai antiinflamasi adalah tanaman kecombrang (Etlingera elatior). Penelitian ini bertujuan untuk mengatahui efektivitas gel ekstrak bunga kecombrang sebagai antiinflamasi terhadap mencit yang diinduksi karagenan. Rancangan penelitian ini menggunakan Randomized Control Group Pretest Posttest Design. Mencit betina sebanyak 25 ekor dibagi ke dalam 5 kelompok yaitu kelompok kontrol negatif, kelompok kontrol positif, kelompok ekstrak 1\%, 2\%, dan 3\%. Telapak kaki mencit disuntikan larutan karagenan $1 \%$ sebanyak $0,1 \mathrm{ml}$ pada area intraplantar. Pengukuran udem menggunakan alat pletismometer. Hasil analisis statistik dengan uji mann whitney menunjukkan adanya perbedaan bermakna antara kelompok kontrol negatif dengan kelompok kontrol positif, kelompok ekstrak $1 \%$, $2 \%$ dan $3 \%$ dengan nilai signifikan secara berturut-turut 0,$009 ; 0,008 ; 0,009 ; 0,009$ (p<0,05). Pada kelompok kontrol positif dengan kelompok ekstrak $3 \%$ tidak terdapat perbedaan bermakna terhadap efek antiinflamasi dengan nilai signifikan sebesar 0,750 ( $>>0,05)$. Dari hasil penelitian yang telah dilakukan dapat disimpulkan bahwa gel ekstrak bunga kecombrang konsentrasi $3 \%$ efektif sebagai antinflamasi pada mencit yang diinduksi karagenan dibandingkan kelompok perlakuan lainnya dalam penelitian ini.
\end{abstract}

Kata kunci: Antiinflamasi, bunga kecombrang, udem

Abstract: Antiinflammation is a drug that has the activity of suppressing or reducing inflammation. In Indonesia there are so many herbal medicinal plants that can be used as anti-inflammatory. One of the plants that is empirically believed to have anti-inflammatory properties is the kecombrang plant (Etlingera elatior). This study aims to determine the effectiveness of kecombrang flower extract gel as an anti-inflammatory against carrageenan induced mice. This research design uses Randomized Control Group Pretest Posttest Design. The 25 female mice were divided into 5 groups, the negative control group, the positive control group, the extract group $1 \%, 2 \%$, and $3 \%$. The sole of the mice's foot is injected with $0.1 \%$ carrageenan solution as much as $0.1 \mathrm{ml}$ in the intraplanar area. Measurement of edema using a plethysmometer. The results of statistical analysis with the Mann Whitney test showed a significant difference between the negative control group and the positive control group, the extract group $1 \%, 2 \%$ and $3 \%$ with significant values respectively 0,$009 ; 0,008$; 0,$009 ; 0,009(\mathrm{p}<0,05)$. In the positive control group with $3 \%$ extract group there was no significant difference on the anti-inflammatory effect with a significant value of $0.750(\mathrm{p}>0.05)$. The results of the research that can be concluded that the $3 \%$ concentration of kecombrang flower extract gel is effective as an anti-inflammatory in carrageenan induced mice compared to other treatment groups in this study.

Key word: Antiinflammatory, kecombrang flower, udema

\section{PENDAHULUAN}

Inflamasi merupakan suatu respon protektif normal terhadap luka jaringan yang disebabkan oleh trauma fisik, zat kimia atau zat-zat mikrobiologik (Mycek, 2001). Inflamasi dapat bersifat lokal dan sistemik, dapat juga terjadi secara akut atau kronis yang menimbulkan kelainan patologis. Gejala inflamasi diantaranya kemerahan, panas, nyeri, bengkak dan gangguan fungsi organ (Corwin, 2008). Pengobatan pada inflamasi dapat menggunakan obat golongan steroid dan antinflamasi non steroid (AINS) yang dapat meredakan reaksi inflamasi dengan baik tetapi penggunaan dalam jangka waktu lama dapat memberikan efek samping. Obat golongan steroid secara sistemik dalam waktu yang lama justru memberikan efek samping berupa penurunan

\footnotetext{
•email korespondensi: kusumawardani210488@gmail.com
} 
respon imun tubuh terhadap infeksi dan osteoporosis serta dapat menimbulkan gangguan saluran pencernaan (Goodman dan Gilman, 2003).

Indonesia adalah negara yang kaya akan tumbuh-tumbuhan. Hutan tropis di Indonesia diperkirakan terdapat 30.000 jenis tumbuhan. Diduga dari jumlah tersebut sekitar 9.600 jenis tumbuhan diketahui berkhasiat sebagai obat (Sriningsih dan Agung, 2006). Namun, belum ada pengkajian lebih dalam tentang khasiat dari tumbuhan-tumbuhan tersebut, salah satunya adalah tumbuhan kecombrang (Etlingera elatior).

Kecombrang (Etlingera elatior) merupakan tumbuhan yang cukup tersebar luas di Indonesia. Kecombrang dapat digunakan mulai dari rimpang hingga bunga. Bunga kecombrang secara empiris sering dimanfaatkan untuk memperlancar ASI, sebagai obat luka serta pemberi cita rasa pada masakan (Hidayat, 1991). Berdasarkan hasil penelitian ilmiah membuktikan adanya aktivitas antibakteri dan antioksidan pada bunga kecombrang (Hudaya, 2010). Uji aktivitas antibakteri ekstrak etanol $70 \%$ bunga kecombrang dapat menghambat pertumbuhan bakteri Shigella dysenteriae dan Vibrio cholera (Nasution, 2015). Bunga kecombrang menunjukkan adanya senyawa flavonoid, tannin, triterpenoid, streroid dan minyak atsiri (Naufalin, dkk., 2010).

Berdasarkan latar belakang di atas perlu dilakukan penelitian tentang efektivitas gel ekstrak bunga kecombrang sebagai antiinflamasi pada mencit yang diinduksi karagenan. Bentuk gel dipilih karena sediaan topikal ini memiliki beberapa keuntungan diantaranya lengket, mudah mengering dan membentuk lapisan film yang tipis sehingga mudah dicuci

\section{METODE PENELITIAN}

Rancangan Penelitian. Jenis penelitian yang digunakan adalah penelitian eksprimental dengan rancangan penelitian Randomized Control Group Pretest Posttest Design.

Alat. Alat pletismometer, timbangan analitik, alat gelas, oven, rotary evaporator, blender, dan spuit 1 cc.

Bahan. Bunga kecombrang yang diperoleh dari Desa Susut, Kabupaten Bangli, Provinsi Bali, etanol $80 \%$, voltaren gel, serbuk karagenan, aquadest, $\mathrm{CMC} \mathrm{Na}$, propilenglikol, metilparaben, asam asetat anhidrat, asam sulfat pekat, serbuk $\mathrm{Mg}$, $\mathrm{HCl}$ pekat dan $\mathrm{FeCl}_{3}$
Populasi dan Sampel. Populasi pada penelitian ini adalah mencit putih galur swiss webster. Sampel yang digunakan dalam penelitian ini adalah mencit putih galur swiss webster yang memenuhi kriteria inklusi dan eksklusi sebagai berikut:

1. Kriteria inklusi
a. Mencit betina
b. Berat badan 20-30 gram
c. Umur 2-4 bulan

\section{Kriteria eksklusi}

Yang termasuk kriteria eksklusi dalam penelitian ini adalah mencit yang sakit atau mati dalam penelitian.

\section{Pembuatan Ekstrak Bunga Kecombrang.} Pembuatan ekstrak bunga kecombrang dilakukan dengan metode maserasi, dengan menggunakan pelarut etanol $80 \%$, serbuk bunga kecombrang sebanyak $200 \mathrm{mg}$ direndam dengan menggunakan pelarut etanol $80 \%$ sebanyak $1.500 \mathrm{ml}$ dilakukan perendaman selama 5 hari di dalam wadah maserasi dengan sesekali diaduk. Kemudian ekstrak disaring dengan menggunakan kertas saring, sehingga diperoleh (filtrat 1) dan sisanya diekstrak kembali selama 1 hari dengan menggunakan $1.200 \mathrm{ml}$ etanol $80 \%$ sehingga diperoleh (filtrat 2) selanjutnya filtrat 1 dan 2 dikumpulkan, diuapkan dengan alat rotary evaporator pada suhu $40^{\circ} \mathrm{C}$ yang bertujuan untuk menguapkan pelarutnya, selanjutnya dipekatkan dengan menggunakan oven pada suhu $40^{\circ} \mathrm{C}$ sampai menjadi ekstrak kental.

Skrining Fitokimia. Skrining fitokimia dilakukan melalui uji reaksi tabung, dengan menggunakan sampel dalam bentuk larutan uji. Pembuatan larutan uji dilakukan dengan melarutkan $300 \mathrm{mg}$ ekstrak kental ke dalam $30 \mathrm{ml}$ pelarut etanol $80 \%$

a. Identifikasi senyawa golongan alkaloid

Sebanyak $2 \mathrm{ml}$ diuapkan dalam cawan porselen hingga didapat residu. Residu kemudian dilarutkan dengan $5 \mathrm{~mL}$ HCL $2 \mathrm{~N}$. Larutan yang didapat kemudian dibagi ke dalam 2 tabung reaksi. Tabung pertama ditambahkan pereaksi Dragendorff sebanyak 3 tetes. Tabung kedua ditambahkan pereaksi Mayer sebanyak 3 tetes. Terbentuknya endapan jingga pada tabung pertama dan endapan putih hingga kekuningan pada tabung kedua menunjukkan adanya alkaloid (Jones and Kinghorn, 2006).

b. Identifikasi senyawa golongan flavonoid

Sebanyak satu gram serbuk ditambah $10 \mathrm{ml}$, air panas, dididihkan selama 5 menit, disaring. Kemudian $5 \mathrm{ml}$ larutan tersebut ditambah serbuk (lempeng) Mg. Kemudian ditambah $2 \mathrm{ml}$ larutan 
alkohol klorhidrat dan ditambah $3 \mathrm{ml}$ larutan amil alkohol. Larutan dikocok kuat dan dibiarkan memisah (bila positif flavonoid, terbentuk warna dalam amil alkohol merah, kuning atau jingga) (Jones and Kinghorn, 2006).

c. Identifikasi senyawa golongan saponin

Ekstrak uji dimasukkan ke dalam tabung reaksi, ditambahkan $10 \mathrm{ml}$ air panas, dinginkan dan kemudian dikocok kuat secara vertikal selama 10 detik. Terbentuk busa atau buih yang stabil selama tidak kurang dari 10 menit setinggi $1-10 \mathrm{~cm}$. Pada penambahan 1 tetes $\mathrm{HCl} 2 \mathrm{~N}$ busa atau buih tidak hilang (Jones and Kinghorn, 2006).

d. Identifikasi senyawa golongan tanin

Sebanyak Larutan ekstrak uji sebanyak $1 \mathrm{~mL}$ direaksikan dengan larutan $\mathrm{FeCl}_{3} 1 \%$. Jika terbentuk larutan berwarna hijau kecokelatan maka (tanin terkondensasi) atau biru kehitaman (tanin terhidrolisis) (Nirwana, dkk., 2015).

e. Identifikasi steroid/terpenoid

Larutan uji sebanyak $2 \mathrm{ml}$ diuapkan, residu yang diperoleh diuapkan dalam $0,50 \mathrm{ml}$ kloroform, lalu ditambah dengan $0,50 \mathrm{ml}$ asam asetat anhidrat. Selanjutnya campuran ditetesi dengan $2 \mathrm{ml}$ asam sulfat pekat melalui dinding tabung tersebut. Bila terbentuk warna hijau kebiruan menunjukkan adanya sterol. Jika hasil yang diperoleh berupa cincin kecoklatan atau violet pada perbatasan dua pelarut, menunjukkan adanya triterpenoid (Jones and Kinghorn, 2006).

Pembuatan Gel Ekstrak Bunga Kecombrang. Pada penelitian ini konsentrasi gel ekstrak bunga kecombrang dibuat dengan beberapa konsentrasi yaitu konsentrasi $1 \%, 2 \%$ dan 3\%. Sediaan gel ekstrak bunga kecombrang menggunakan $\mathrm{CMC} \mathrm{Na}$ sebagai gelling agent, propilenglikol sebagai humektan dan metilparaben sebagai pengawet.

Tabel 1. Formula gel ekstrak bunga kecombrang

\begin{tabular}{lllccc}
\hline \multirow{2}{*}{ No } & \multirow{2}{*}{ Nama bahan } & Kegunaan & \multicolumn{3}{c}{$\begin{array}{c}\text { Formulasi gel ekstrak bunga } \\
\text { kecombrang }\end{array}$} \\
\cline { 3 - 6 } & & Zat aktif & $1 \%$ & $2 \%$ & $3 \%$ \\
\hline $\mathbf{1}$ & Ekstrak & F1 & F2 & F3 \\
$\mathbf{2}$ & Na-CMC & Basis gel & $3 \%$ & $3 \%$ & $3 \%$ \\
$\mathbf{3}$ & Propilenglikol & Humektan & $15 \%$ & $15 \%$ & $15 \%$ \\
$\mathbf{4}$ & Metil paraben & Pengawet & $0,2 \%$ & $0,2 \%$ & $0,2 \%$ \\
$\mathbf{5}$ & Aquadest & Pembawa & ad 20 g & Ad 20 g & ad 20 g \\
\hline
\end{tabular}

Penyiapan Induktor Radang Karagenan $1 \%$. Ditimbang sebanyak 0,1 gram karagenan dilarutkan dalam $100 \mathrm{ml}$ aquadest, kemudian disuntikkan secara intraplantar $0,1 \mathrm{ml}$ pada telapak kaki kiri mencit.

Uji Efektivitas Antiinflamasi. Pengujian efektivitas antiinflamasi dilakukan dengan metode pembentukan udem buatan dengan menggunakan induksi karagenan. Mencit betina sebanyak 25 ekor dibagi menjadi 5 kelompok yaitu kelompok kontrol negatif (diberi basis gel), kelompok kontrol positif (diberi voltaren gel), kelompok perlakuan 1 (diberi gel ekstrak bunga kecombrang 1\%), kelompok perlakuan 2 (diberi gel ekstrak bunga kecombrang 2\%), kelompok perlakuan 3 (diberi gel ekstrak bunga kecombrang 3\%), kemudian masing-masing mencit diberi suspensi karagenan sebanyak $0,1 \mathrm{ml}$ secara intraplantar pada telapak kaki kiri, setelah 30 menit diukur volume udem pada alat pletismometer. Selanjutnya masing-masing mencit diberi perlakuan sesuai dengan kelompok pengukuran, dilakukan selama 6 jam. Untuk meminimalkan keterbatasan penelitian, pengamatan inflamasi dalam penelitian ini dilakukan oleh tim sehingga diharapkan hasilnya lebih objektif dan presisi.

\section{Pengolahan dan Analisis Data}

Data yang diperoleh diuji secara statistik dengan program SPSS 22 for windows menggunakan metode analisis Shapiro-Wilk yang dilanjutkan dengan uji kruskal wallis dan mann-whiteney.

\section{HASIL DAN PEMBAHASAAN}

\section{Ekstrak Bunga Kecombrang}

Setelah didapat maserat kemudian dipekatkan dan didapatkan ekstrak kental sebanyak 16,3 gram dengan hasil rendemen ekstrak sebanyak 18,5\%.

\section{Skrining Fitokimia}

Berdasarkan hasil skrining fitokimia, ekstrak bunga kecombrang mengandung senyawa flavonoid, saponin, tannin dan terpenoid. Hasil pengujian skrining fitokimia dapat dilihat pada Tabel 2.

Tabel 2. Hasil Skrining Fitokimia Ekstrak Bunga Kecombrang

\begin{tabular}{lll}
\hline $\begin{array}{l}\text { Metabolit } \\
\text { sekunder }\end{array}$ & \multicolumn{1}{c}{ Pengamatan } & Ket \\
\hline $\begin{array}{l}\text { Steroid dan } \\
\text { triterpenoid }\end{array}$ & Terbentuk cincin berwarna ungu & + \\
Flavanoid & Terbentuk cincin berwarna merah & + \\
Saponin & $\begin{array}{l}\text { Terdapat busa yang konsisten } \\
\text { Terbentuk cincin berwarna hijau }\end{array}$ & + \\
Tanin & \begin{tabular}{l} 
coklat \\
\hline
\end{tabular}
\end{tabular}

Keterangan: (+): Ada

Pengaruh Karagenan terhadap Inflamasi. Karagenan merupakan senyawa hidrokoloid yang terdiri dari natrium, kalium sulfat, ester kalium, dan magnesium. Karagenan berperan dalam pembentukan udem. Karagenan merupakan suatu zat asing yang bila masuk ke dalam tubuh akan 
merangsang pelepasan mediator radang seperti histamine sehingga menimbulkan radang akibat antibodi tubuh bereaksi terhadap antigen tersebut untuk melawan pengaruhnya (Necas, 2013). Pada saat terjadi pelepasan mediator inflamasi terjadi edema dan bertahan beberapa jam. Inflamasi yang diinduksi oleh karagenan ditandai dengan peningkatan rasa sakit, pembengkakan, dan sintesis prostaglandin hingga 4-5 kali. Edema yang disebabkan induksi karagenan bertahan selama 6 jam dan berangsur-angsur berkurang dalam waktu 24 jam (Taufiq, et al., 2008).

\section{Pengukuran Efektivitas Antiinflamasi.} Pengukuran efektivitas antiinflamasi dilakukan dengan cara melihat kemampuan gel ekstrak bunga kecombrang mengurangi volume udem kaki mencit akibat induksi suspensi karagenan. Pada Tabel 3. dapat dilihat hasil pengukuran rata-rata volume udem kaki mencit pretest dan posttest

Tabel 3. Hasil Pengukuran Rata-rata Volume Kaki mencit Pretest dan Posttest

\begin{tabular}{|c|c|c|c|}
\hline \multirow[b]{2}{*}{ Kelompok } & \multicolumn{2}{|c|}{ Perlakuaan } & \multirow{2}{*}{$\begin{array}{c}\text { Selisih rata-rata } \\
\text { penurunan volume } \\
\text { udem }\end{array}$} \\
\hline & $\begin{array}{c}\text { Pretest } \\
(\mathrm{ml})\end{array}$ & $\begin{array}{c}\text { Posttest } \\
(\mathrm{ml})\end{array}$ & \\
\hline Kontrol negatif & 0,372 & 0,506 & $-0,134$ \\
\hline Kontrol positif & 0,368 & 0,202 & 0,166 \\
\hline Gel ekstrak $1 \%$ & 0,388 & 0,258 & 0,130 \\
\hline Gel ekstrak $2 \%$ & 0,394 & 0,258 & 0,152 \\
\hline Gel ekstrak 3\% & 0,38 & 0,206 & 0,174 \\
\hline
\end{tabular}

Keterangan:

- $\quad$ : Tidak terjadi penurunan inflamasi

Hasil pengukuran menunjukkan rata-rata volume udem pada kelompok kontrol negatif mengalami peningkatan sampai jam ke-6, sedangkan pada kelompok kontrol positif, kelompok perlakuan $1 \%$, $2 \%$, dan $3 \%$ mengalami penurunan volume udem.

\section{$\bar{\varepsilon} \quad$ Rata-rata volume udem}

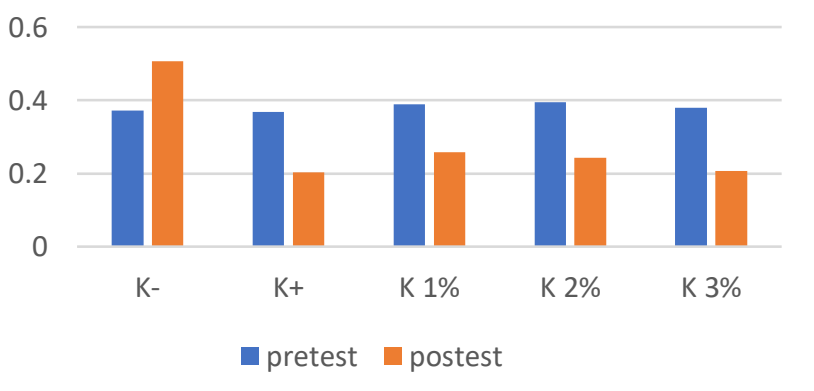

Gambar 1. Rata-rata volume udem pretest dan posttest

\section{Analisa Statistik}

Hasil uji normalitas menunjukkan data yang dihasilkan tidak terdistribusi normal, hal ini ditunjukkan dari adanya kelompok yang memiliki nilai $\mathrm{p}<0,05$. Hasil uji kruskal wallis menunjukkan nilai signifikansi 0,001 pada hasil posttest, hal ini menunjukkan sedikitnya terdapat dua kelompok yang memiliki data berbeda bermakna, untuk melihat kelompok mana yang memiliki perbedaan bermakna dilakukan uji mann whitney.

Tabel 4. Hasil Uji Mann-Whitney

\begin{tabular}{ccc}
\hline Kelompok & Kelompok & Nilai p \\
\hline \multirow{3}{*}{ Kontrol - } & Kontrol + & 0,009 \\
& Ekstrak 1\% & 0,008 \\
& Ekstrak 2\% & 0,009 \\
& Ekstrak 3\% & 0,009 \\
Kontrol + & Ekstrak 1\% & 0,009 \\
& Ekstrak 2\% & 0,028 \\
Ekstrak 1\% & Ekstrak 3\% & 0,750 \\
Ekstrak 2\% & Ekstrak 2\% & 0,502 \\
& Ekstrak 3\% & 0,008 \\
\hline
\end{tabular}

Hasil uji mann whitney menunjukkan adanya perbedaan bermakna antara kelompok kontrol negatif dengan kelompok kontrol positif, kelompok ekstrak $1 \%, 2 \%$ dan $3 \%$ dengan nilai signifikan secara berturut-turut 0,$009 ; 0,008$; 0,009; 0,009 ( $<<0,05)$. Pada kelompok kontrol positif dengan kelompok ekstrak 3\% tidak terdapat perbedaan bermakna terhadap efek antiinflamasi dengan nilai signifikan sebesar 0,750 ( $p>0,05)$.

Adanya pengaruh antiiflamasi pada kelompok ekstrak diduga karena adanya senyawa flavonoid. Flavanoid secara khusus mampu menghentikan pembentukan dan pengeluaran zatzat yang menyebabkan peradangan akibat reaksi alergi. Senyawa-senyawa yang termasuk dalam golongan flavonoid mempunyai efek yang berbeda-beda dalam inflamasi. Mekanisme antiinflamasi yang dilakukan oleh flavonoid dapat melalui beberapa jalur yaitu menghambat aktivitas enzim COX dan lipooksigenase secara langsung yang menyebabkan penghambatan biosintesis prostaglandin dan leukotriene yang merupakan produk akhir dari jalur COX dan lipooksigenase. Hal ini dapat menghambat akumulasi leukosit dan degranulasi netrofil sehingga secara langsung mengurangi pelepasan asam arakidonat oleh netrofil, serta menghambat pelepasan histamine. Pada kondisi normal leukosit bergerak bebas sepanjang dinding endotel. Selama inflamasi berbagai mediator turunan endotel dan faktor kompelemen menyebabkan adhesi leukosit ke dinding endotel. Pemberian flavonoid dapat menurunkan jumlah leukosit dan mengurangi aktivasi komplemen sehingga menurunkan adhesi leukosit ke endotel dan mengakibatkan penurunan respon inflamasi (Nijveldt, dkk., 2001) 
Senyawa terpenoid diduga memberikan aktivitas antiinflamasi karena senyawa ini dapat menghambat produksi TNF- $\alpha$ (tumour necrosis factor) yang merupakan sitokin proinflamasi. Terpenoid juga dapat menghambat ekspresi COX2 sehingga prostaglandin yang terbentuk selama proses radang dapat dikurangi (Bellik, dkk., 2013). Senyawa tannin mempunyai aktivitas antioksidan, antioksidan berperan sebagai antiinflamasi dengan cara menghambat produksi oksidan $\left(\mathrm{O}_{2}\right)$ oleh neutrophil, monosit dan makrofag. Penghambatan produksi oksidan $\mathrm{O}_{2}$ akan mengurangi pembentukan $\mathrm{H}_{2} \mathrm{O}_{2}$ yang mengakibatkan produksi asam hipoklorid dan radikal hidroksi ikut terganggu (Robinson, 1995)

\section{SIMPULAN}

Dari hasil penelitian yang telah dilakukan dapat disimpulkan bahwa gel ekstrak bunga kecombrang konsentrasi $3 \%$ secara statistik memiliki efektifitas yang tidak berbeda dengan kontrol positif sebagai antinflamasi pada mencit yang diinduksi karagenan.

\section{DAFTAR PUSTAKA}

Bellik Y, Boukraa L, Alzahrani H.A, Bakhotmah B.A, Abdellah F, Hammoudi S.M, IguerOuada M. 2013. Review: molecular mechanism underlying antiinflammatory and anti-allergic activities of phytochemicals: an update. Molecules. 18: $322-353$

Corwin, E.J. 2008 Handbook of Pathophysiology, 3th Edition. Philadelphia: Lippincort Williams dan Wilkins.

Goodman \& Gilman's, 2003, Dasar farmakologi Terapi Edisi 10, Volume 2, Penerbit Buku Kedokteran EGC, Jakarta

Hidayat, S., \& Hutapea, J. 1991. Investasi Tanaman Obat Indonesia, Edisi 1: 440441. Badan Penelitian dan Pengembangan Depkes RI.
Hudaya, A. 2010. Uji antioksidan dan antibakteri ekstrak air bunga kecombrang (Etlingera elatior) sebagai pangan fungsional terhadap Staphylococcus aureus dan Escheria coli. Program studi biologi, FST, Universitas Islam negeri Syarif Hidayarullah, Jakarta.

Jones, W. P. and A. D. Kinghorn, 2006, Extraction of Plant Secondary Metabolites. In: Sarker, S. D., Latif, Z. and Gray, A. I., eds. Natural ProductsIsolation. 2nd Ed. New Jersey: Humana Press. P.341-342.

Mycek, M.J. 2001 Farmakologi Ulasan Bergambar, edisi 2. Jakarta: Widya Medika.

Nasution, A.A. 2015. Uji Aktivitas Antibakteri Ekstrak Etanol Bunga Kecombrang (Nicolaia speciosa Horan) terhadap Bakteri Shigella dysentriae dan Vibrio cholera secara in vitro. Thesis. Yogyakarta: Fakultas Kedokteran dan Ilmu Kesehatan Universitas Muhammadiyah.

Naufalin, R. 2005. Kajian Sifat Antimikroba Bunga Kecombrang (Nicolaia speciosa Horan) Terhadap Berbagai Mikroba Patogen dan Perusak Pangan. Disertasi. Sekolah Pascasarjana, Institut Pertanian Bogor, Bogor. 181 hal (Tidak dipublikasikan)

Necas, J., Bartosikova, L. (2013). Carrageenan: a review, Faculty of Medicine and Dentistry. Palacky University. Olomouc. Czech Republic: Veterinarni Medicina. 58 (4): 187-205.

Nijveldt, R.J., Nood, E.V., Hoorn, D.E.C., Boelens P.G., Norren K.V., dan Leeuwen, P.A.M. 2001. Flavonoids: A Review of Proabable mechanisms of action and potential Application. Am JCLIN Nutr. $74: 418-425$

Nirwana, A.P., Astirin, O.P dan Widiyani, T. 2015. Skrining Fitokimia Ekstrak Etanol Daun Benalu Kersen (Dendrophtoe pentandra L. Miq.). EL-VIVO 3(2): 9-15 
Robinson, T. 1995. Kandungan Organik Tumbuhan Tingkat Tinggi. Penerbit ITB. Bandung

Sriningsih dan Agung E.W. 2006 Efek Protektif Pemberian Ekstrak Etanol Herba Meniran (Phyllantus niruri L.) terhadap Aktivitas dan Kapasitas Fagositosis Makrofag Peritoneum Tikus, dalam: Artocarpus Media Pharmaceutica Indonesia Vol. 6(2). Fakultas Farmasi Universitas Surabaya, Surabaya: 91-96

Taufiq H, Lukman, et al. 2008. Efek Antiinflamasi Ekstrak Patikan kebo (Euphorbia hirta L.) Pada Tikus Putih Jantan. Pharmacon, Vol. 9, No. 1, 1-5 